\title{
BONET NAVARRO, JOSÉ (2007). Los juicios por desahucio. Especialida- des procesales para la recuperación de la finca arrendada o en situa- ción de precario. Navarra: Aranzadi, 397 pp.
}

El profesor Bonet Navarro es un destacado procesalista, profesor titular de la Facultad de Derecho de la Universidad de Valencia, España, autor de un importante número de obras individuales y colectivas.

Además de su vasta labor científica dedicada al estudio del proceso civil espańol, no podemos dejar de mencionar los estrechos vínculos del profesor Bonet con la actividad jurídica de nuestro país como profesor visitante del Doctorado en Derecho de la Pontificia Universidad Católica de Chile, además de haber participado en distintas actividades académicas relacionadas con el anteproyecto del Código de Procedimiento Civil chileno, habiendo publicado algunos artículos de gran interés relacionados con la reforma proyectada ${ }^{1}$.

El autor, en la presentación de la obra, da cuenta de las implicancias políticas, económicas y sociales del fenómeno arrendaticio en Espańa y del tránsito que a lo largo de la historia moderna de ese país ha tenido tal institución, pasando desde una voluntad política tendente a atemperar el movimiento liberalizador de la propiedad urbana, lo que ayudó a incrementar la ya escasa utilización e inversión en la vivienda arrendada, para luego, a través del denominado "Decreto Boyer" (1985), liberalizar sustancialmente el contrato de arrendamiento, especialmente en cuanto a su duración, excluyendo la prórroga forzosa. En ese momento, la institución pasó a ser eminentemente inestable pues además de su corta duración, se produjo un aumento excesivo de las rentas, aumento que pasó a ser condición necesaria para la renovación del contrato. Así las cosas, la Ley de Arrendamientos Urbanos de 1994 (LAU/1994) intentó establecer un marco al decir del autor de "pretendido equilibrio", hasta la última reforma de la Ley de Enjuiciamiento Civil española (LECiv).

El autor hace un análisis de los efectos de las sucesivas modificaciones legislativas en la materia anotando que, por ejemplo, la liberalización de 1985 no estuvo acompańada del pretendido aumento de viviendas disponibles para alquiler. Pues bien, la razón de ello estaría dada por el alto número de viviendas que se encuentran sometidas a legislaciones anteriores a

Bonet Navarro, José (2008). "La realización sustitutiva de la subasta judicial en el Anteproyecto de Código Procesal Civil". Revista de Derecho, Universidad Católica del Norte, ańo 15 No 1, pp. 21-59 y Bonet NaVArRo, José (2007). "El procedimiento monitorio en el anteproyecto de código procesal chileno. Algunas consideraciones a partir de la experiencia en Derecho español". Revista de Derecho. Universidad Católica del Norte, ańo 14 No 2, pp. 43-78. 
la entrada en vigor de esta normativa liberalizadora, las que se encuentran atadas a prórrogas forzosas y la imposibilidad práctica de aumentar las rentas a niveles de mercado. Ahí está, según Bonet, la raíz del problema: siendo el contrato de arrendamiento marcadamente favorable al inquilino, este tiende a no desistir del mismo sin posibilidad práctica de desahucio del mismo, fenómeno que contextualiza (aunque no justifica) ciertas conductas de parte de los arrendadores denominadas mobbing inmobiliario.

Una vez hecha esta contextualización del fenómeno o problema arrendaticio en España, el autor declara cuál es el objeto de la obra que hoy comentamos, cual es, dentro de la perspectiva jurídica del fenómeno arrendaticio, el estudio de los instrumentos procesales que el ordenamiento jurídico espańol pone a disposición fundamentalmente del arrendador que pretende la efectividad práctica de la extinción contractual, es decir, la recuperación de la posesión del inmueble arrendado o en aparecería.

La obra se encuentra dividida en cinco capítulos y tres interesantes anexos de práctica forense que contienen apuntes y formularios de los juicios verbal y ordinario, que son las formas procedimentales que actualmente establece la legislación española.

El Capítulo I de la "tipología procedimental para el desahucio: adecuación, cuantificación y objeto", el autor refiere a la voluntad del legislador español de sistematizar las diversas y dispersas normas que regulan el arrendamiento en el ordenamiento jurídico espańol. En este sentido, en consonancia con la voluntad legislativa, Bonet opina que la regulación preexistente se encontraba contenida muchas veces en normas que solamente debían contener derecho material, manteniendo como denominador común el aspecto procedimental, todo ello evidente sin la pretensión de unificar a ultranza, sino suprimir lo que resulta innecesario, poniendo término a una dispersión normativa excesiva. Se pasa entonces, de una pluralidad de procesos especiales en diversas leyes materiales a distintas especialidades en la LECiv. Quedan en la LECiv preordenadas todas las pretensiones basadas en materia arrendaticia, y evidentemente el desahucio como aspecto más relevante, a los trámites del juicio verbal u ordinario, manteniendo gran parte de las especialidades preexistentes, explicando el autor que dichas especialidades varían cuantitativa y cualitativamente en función de la causa en que se funde la recuperación del inmueble.

El Capítulo segundo se ocupa de ciertos aspectos procesales de carácter general y otros especiales relativos a todo juicio de desahucio, tales como la capacidad, legitimación, pluralidad de partes y litisconsorcio, jurisdicción y competencia. Llama nuestra atención en este capítulo la norma contenida en el artículo 449 LECiv a que hace referencia el autor que prescribe: "en los procesos que lleven aparejado el lanzamiento, no se admitirán al demandado los recursos de apelación, extraordinario por infracción procesal o casación si, al prepararlos, no manifiesta, acreditán- 
dolo por escrito, tener satisfechas las rentas vencidas y las que con arreglo al contrato deba pagar adelantadas". Sin duda, una norma como esta en nuestra regulación del contrato de arrendamiento de bienes raíces merecería un interesante debate, incluso a nivel de constitucional.

El capítulo tercero se ocupa de las especialidades procesales por motivos diversos: desahucio por precario y arbitral. Resaltamos en este capítulo la opinión del autor en relación a los graves inconvenientes y disfunciones que plantearía la cláusula de sometimiento a arbitraje, tales como la reducida posición negociadora en que se encuentra el arrendatario, así como también ciertos inconvenientes prácticos, como por ejemplo, decidir qué previsiones conviene o es posible introducir en el procedimiento arbitral, así como también la desventaja jurídico procesal a la que pudiese verse enfrentada alguna de las partes al no poder contar con las garantías que le otorga el proceso sometido a la jurisdicción ordinaria.

El capítulo cuarto trata de las especialidades procesales exclusivas del juicio verbal de desahucio por extinción del plazo y por falta de pago.

Por último, el capítulo quinto estudia pormenorizadamente las medidas cautelares y la ejecución provisional y definitiva. En este punto, resulta relevante el análisis crítico que realiza el autor respecto de la tesis de inadmisión de la ejecución provisional en los juicios por desahucio por falta de pago.

La obra del profesor Bonet Navarro que ocupa estas líneas constituye un estudio detallado y pormenorizado de los juicios por desahucio, como aspecto fundamental dentro del fenómeno arrendaticio en Espańa. Tiene como virtud, a mi juicio, presentar de manera clara, pormenorizada y con la rigurosidad científica necesaria la institución del desahucio en la legislación española justificando, dentro de un análisis si se quiere sociológicojurídico de la realidad, la necesidad de unas normas procesales que permitan el desarrollo inmobiliario pero otorgando a las partes contratantes las garantías necesarias dentro del proceso. Sin duda, la lectura de "Los juicios por desahucio" del profesor Bonet Navarro resulta de gran interés para nuestra comunidad jurídica, puesto que la legislación civil española es siempre un referente para el legislador chileno.

\section{Pamela Astorga Páez*}

Abogada. Magíster de Derecho de los Negocios, Universidad Adolfo Ibáńez. Profesora de Derecho Procesal, Universidad Católica del Norte. Correo electrónico: astorga@ucn.cl 